\title{
Clinical Trial of Cephaloridine (Ceporin), a New Broad-spectrum Antibiotic Derived from Cephalosporin C
}

\author{
J. MCC. MURDOCH, F F.R.C.P.ED., M.R.C.P.GLASG. ; C. F. SPEIRS, * M.B., CH.B. ; \\ A. M. GEDDES,* M.B., M.R.C.P.ED. ; E. T. WALLACE,* F.I.M.L.T.
}

Brit. med. F., 1964, 2, 1238-1240

In a search for new antibiotic substances, Brotzu isolated a fungus from the sea near a sewage outfall in Sardinia in 1945. He used an extract of this for the parenteral treatment of patients suffering from typhoid fever and from infection with Brucella melitensis, and appears to have achieved some success. A culture of the organism was received in Oxford, where seven antibiotic substances were isolated from it (Florey, 1955). Three of these were cephalosporin N, a penicillin which is active mainly against Gram-negative organisms and is identical with synnematin $B$, which has a therapeutic action in typhoid fever ; cephalosporin $\mathrm{P}$, which has a steroid structure and is related to the more recently discovered fusidic acid (fucidin); and cephalosporin C, of which 7-aminocephalosporanic acid is the nucleus (Loder et al., 1961 ; Brit. med. F., 1964). The nucleus of cephalosporin $C$ is closely related to the penicillin nucleus, 6-aminopenicillanic acid, but differs from the latter in having a fused dihydrothiazine $\beta$-lactam ring instead of a fused thiazolidine $\beta$-lactam ring (Loder et al., 1961 ; Barber and Waterworth, 1964).

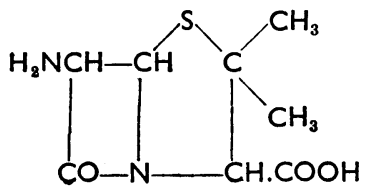

6-aminopenicillanic acid.

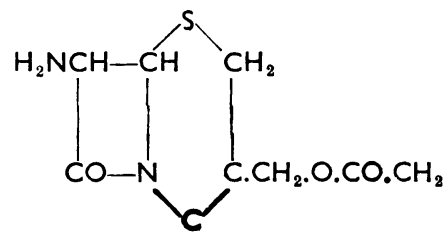

7-aminocephalosporanic acid.
Synthetic manipulation of the cephalosporin nucleus is now possible and 7-(thiophene-2-acetamido)-cephalosporanic acid (cephalosporin $87 / 1$ or cephalothin) is already in use in the United States (Anderson and Petersdorf, 1962 ; Walters et al., 1962).

Another new compound, cephaloridine, 7-[(2-thienyl)acetamido]-3-(1-pyridylmethyl)-3-cephem-4-carboxylic acid betaine, Ceporin, has been produced chemically from cephalosporin C at Glaxo Laboratories. This has a broad spectrum of activity against many Gram-positive and Gram-negative bacteria in vitro. Sensitive organisms include Staphylococcus aureus (including penicillin-resistant strains), Streptococcus pneumoniae, Str. pyogenes, Str. viridans, Corynebacterium diphtheriae, Neisseria catarrhalis and N. gonorrhoeae, Clostridium septicum and Cl. welchii, Escherichia coli, Salmonella typhi, S. typhimurium, S. paratyphi, various Shigella spp., Proteus mirabilis, and Bordetella pertussis. Leptospira icterohaemorrhagiae, Proteus vulgaris, and Pseudomonas pyocyanea are insensitive. It has no action against fungi, protozoa, or helminths and has only low activity against Mycobacterium tuberculosis.

The antibiotic is highly bactericidal in its action, particularly against Gram-negative organisms. For example, against $E$. coli the addition of cephaloridine to a growing culture at the minimum inhibitory concentration (M.I.C.) causes a very rapid kill of more than $99.99 \%$ of the cells followed by their lysis.

* From the City Hospital, Edinburgh.
Resistance development in vitro takes place in a slow stepwise manner. The development of resistance by Staph. aureus is independent of the sensitivity of the strains to penicillin. It is 100-1,000 times more resistant to Staph. aureus penicillinase than is penicillin $\mathrm{V}$, and therefore for practical purposes it is unaffected. The resistant strains of Aerobacter aerogenes and Proteus spp. can destroy the antibiotic, presumably by producing a lactamase.

Absorption after oral administration is poor and the drug must be given by parenteral injection, which is comparatively painless. Peak serum levels are obtained 15 to 30 minutes after intramuscular injection, and good serum levels can be maintained for six to eight hours. There appears to be no significant degree of protein-binding in serum. High levels are obtained in renal tissue and inflamed muscle. The level in bile is not higher than in the serum, and it would not appear to be excreted in this way. It is stable in the body and is excreted unchanged in the urine, high levels being attained.

The present trial was planned to assess the clinical value of cephaloridine in the treatment of various infections due to Gram-positive and Gram-negative organisms.

\section{Patients and Methods}

\section{Clinical}

Thirty-three females and 10 males, whose ages ranged from 6 to 72 years, were treated with cephaloridine. They suffered from a variety of Gram-positive and Gram-negative infections, divided into four groups: (A) pyelonephritis, (B) septicaemia, (C) septic meningitis, and (D) miscellaneous infections.

Group A.-Twenty-four female and five male patients with pyelonephritis were treated, most of whom had refractory urinary infections not previously eradicated by other antibiotics. In 13 patients there was radiological evidence of structural renal damage. Vesico-ureteric reflux was present in two children. Adult patients were given cephaloridine intramuscularly in doses of $500 \mathrm{mg}$. six-hourly and children $250 \mathrm{mg}$. six-hourly. After a 14-day course of treatment all patients were followed up for evidence of clinical and/or bacteriological relapse. Four patients were followed up for three days, 11 for four weeks, five for eight weeks, and four for 12 weeks. In the remaining five cases relapse occurred immediately treatment was discontinued.

Group B.-Details of the six patients in this group are shown in Table I.

Table I.-Group B Patients with Septicaemia

\begin{tabular}{|c|c|c|c|c|}
\hline Age & $\begin{array}{l}\text { Organism } \\
\text { (M.I.C. } \mu \mathrm{g} . / \mathrm{ml} .)\end{array}$ & $\begin{array}{l}\text { Daily } \\
\text { Dose }\end{array}$ & Result & Comment \\
\hline 64 & E. $\operatorname{coli}(8)$ & l'g. & Success & Uraemia. Requ \\
\hline $\begin{array}{l}55 \\
61 \\
64 \\
72 \\
32\end{array}$ & $\begin{array}{l}\text { E. coli (16) } \\
\text { Pneumococcus (4) } \\
\text { E. coli }(4) \\
\text { Coliforms (-) } \\
\text { Staph. aureus (0.5) }\end{array}$ & $\begin{array}{l}3 \mathrm{~g} . \\
2 \mathrm{~g} . \\
2 \mathrm{~g} . \\
2 \mathrm{~g} . \\
2 \mathrm{~g} .\end{array}$ & $\begin{array}{l}\text { Failure } \\
\text { Success } \\
\text { Success } \\
\text { Died } \\
\text { Died }\end{array}$ & $\begin{array}{l}\text { Bacteroides superinfection } \\
\text { Diabetic } \\
\text { Bilateral hydronephrosis } \\
\text { Leukaemia } \\
\text { Thrombocytopenic purpura }\end{array}$ \\
\hline
\end{tabular}


Group C.-Four cases of septic meningitis were treated. Pneumococci were cultured from the C.S.F. in two cases, but in the other two, although Gram-positive diplococci were seen on direct films of C.S.F., culture was sterile. Cephaloridine was administered intramuscularly in doses of $500 \mathrm{mg}$. sixhourly and by daily intrathecal injections of $50 \mathrm{mg}$. or $100 \mathrm{mg}$. in $20 \mathrm{ml}$. of saline. A 36-year-old woman developed pneumococcal meningitis while on steroid therapy for thrombocytopenic purpura. She was known to be hypersensitive to penicillin but responded dramatically to cephaloridine. A 29-year-old man with surgically induced hypopituitarism was admitted to hospital in a semicomatose state with severe septic meningitis. Organisms morphologically resembling pneumococci were seen on direct films of C.S.F. and treatment was started with massive doses of benzylpenicillin by both intramuscular and intrathecal routes. In spite of this the patient's condition continued to deteriorate and treatment was changed to cephaloridine. Within 24 hours there was marked improvement and subsequent recovery was entirely satisfactory. A third patient had septic meningitis secondary to a ruptured cerebral abscess, and the fourth had uncomplicated pneumococcal meningitis.

Group D.-Two of the patients in this group had chest infections following crush chest injuries necessitating tracheostomy-one also had an empyema. In neither of these cases were pathogens cultured from sputum. A third patient had acute ulcerative endocarditis with renal failure but sterile blood cultures, and the fourth had a pelvic abscess from which $E$. coli was cultured. In all four cases previous antibiotic therapy had been unsuccessful. Cephaloridine was given in a daily dose of $2 \mathrm{~g}$. in this group.

\section{Bacteriological}

Group A.-In all cases mid-stream specimens of urine (M.S.S.U.) were collected, using a standard technique (Sleigh et al., 1964). At least one and in most cases three M.S.S.U. were taken before treatment was started. Two further specimens were taken on the third and tenth days of treatment and two after treatment. After collection the specimens were either examined immediately or stored at $4^{\circ} \mathrm{C}$. The number of viable organisms was estimated by the method of Miles and Misra (1938), bacterial counts of 100,000 organisms per ml. or more being taken as significant. Only patients with significant bacteriuria were included in the trial. The M.I.C. of each organism for cephaloridine was determined, using a tubedilution method (Murdoch et al., 1962).

Group B.-Venous blood was inoculated into nutrient broth, and after 24 hours' incubation subcultures were made on bloodagar plates and incubated aerobically, anaerobically, and in an atmosphere of $10 \% \mathrm{CO}_{2}$. The M.I.C. of the organisms was determined as for group A.

Group C.-Purulent C.S.F. was examined on direct Gramstained films and was also cultured on chocolate-agar plates aerobically and on blood-agar plates in an atmosphere of $10 \%$ $\mathrm{CO}_{2}$. The M.I.C. of the organisms was determined as for group A.

Group D.-Pus and sputum specimens were examined on direct Gram-stained films. The pus was cultured on bloodagar aerobically and anaerobically, and the sputum was cultured on blood-agar aerobically. The M.I.C. of the organism was determined as for group A.

\section{Levels of Cephaloridine in Body Fluids}

The level of cephaloridine in serum, urine, C.S.F., pleural fluid, and bile was measured by chemical and bioassay methods.

Chemical estimations of cephaloridine in serum, urine, C.S.F., pleural fluid, and bile were made using the method of
Griffen and Child (personal communication). The antibiotic was first hydrolysed with dilute $\mathrm{HCl}$ to yield pyridine, which was subsequently estimated by conversion to a fluorescent Schiff's base with cyanogen bromide and aniline. In some instances microbiological assays were also performed on the same samples. The values stated in this paper are those obtained by the chemical assay method.

\section{Results}

Treatment was successful in 23 of the 43 patients treated with cephaloridine. There were 16 bacteriological failures and four deaths.

Group A.-E. coli was the infecting organism in 16 patients in this group, Proteus spp. in seven, enterococci in three, Klebsiella spp. in one, paracolons in one, and Staph. aureus in one. Initial urine sterility was achieved in all 29 patients with pyelonephritis. Five patients relapsed immediately treatment was discontinued and a further eight during the next eight weeks. In eight of these treatment failures the pyelographic appearances were abnormal, and two had significant vesico-ureteric reflux.

Group B.-Treatment was successful in three of the six septicaemic patients and there were two deaths. One of the patients who died was a 72-year-old man with leukaemia, and the other was a young woman with thrombocytopenic purpura and ulcerative endocarditis. Bacteroides superinfection caused failure of treatment in one patient. One of the successfully treated patients who was uraemic required two courses of cephaloridine.

Group C.-Two patients with septic meningitis responded satisfactorily to one course of cephaloridine. A third patient relapsed three months after apparently successful treatment and required a second course of the antibiotic. The patient who died in this group had a cerebral abscess: death followed neurosurgery.

Group D.-Treatment was successful in two patients in this group and there was one death due to renal failure. Superinfection with Ps. pyocyanea necessitated change of antibiotic in a young man with a tracheostomy and chest infection.

\section{Bacteriology}

Table II shows the results of tube-dilution sensitivities of 146 organisms tested against cephaloridine. The majority of $E$. coli species were sensitive to $8 \mu \mathrm{g} . / \mathrm{ml}$. or less of the antibiotic.

TABLE II.-Minimum Inhibitory Concentration of 146 Organisms Tested

\begin{tabular}{|c|c|c|c|c|c|c|c|c|c|}
\hline \multirow{2}{*}{\multicolumn{2}{|c|}{ Organism }} & \multirow{2}{*}{$\begin{array}{l}\text { No. of } \\
\text { Strains }\end{array}$} & \multicolumn{7}{|c|}{ Minimum Inhibitory Concentration ( $\mu \mathrm{g} . / \mathrm{ml})}$. \\
\hline & & & $\leqslant 2$ & 4 & 8 & 16 & 32 & 64 & $>64$ \\
\hline $\begin{array}{l}\text { E. coli } \\
\text { Proteus spp. } \\
\text { Enterococci } \\
\text { Staphylococci } \\
\text { Paracolons } \\
\text { Klebsiellae } \\
\text { Pneumococci }\end{array}$ & $\begin{array}{l}. . \\
\because \\
\because \\
\cdots \\
\cdots\end{array}$ & $\begin{array}{r}99 \\
25 \\
8 \\
6 \\
4 \\
2 \\
2 \\
\end{array}$ & $\begin{array}{l}4 \\
2 \\
6\end{array}$ & $\begin{array}{r}43 \\
1 \\
1 \\
1\end{array}$ & $\begin{array}{r}37 \\
9 \\
1 \\
\\
1\end{array}$ & $\begin{array}{l}7 \\
7 \\
3\end{array}$ & $\begin{array}{l}1 \\
1 \\
1\end{array}$ & $\begin{array}{l}2 \\
1\end{array}$ & $\begin{array}{l}5 \\
7\end{array}$ \\
\hline Total $\ldots$ & . & 146 & 14 & 46 & 48 & 17 & 3 & 4 & 14 \\
\hline
\end{tabular}

\section{Levels of Cephaloridine in Body Fluids}

Eighty estimations of serum cephaloridine levels one hour after an intramuscular dose of $500 \mathrm{mg}$. were carried out, and the results are shown in Table III.

Table IV shows the results of cephaloridine assay in 87 aliquots of 24-hour collections of urine during treatment with a daily dose of $2 \mathrm{~g}$. 
TABLE III.-Serum Levels of Cephaloridine (80 Assays Taken One Hour After Intramuscular Injection)

\begin{tabular}{ll|c|c|c|c|c|c|c|c|c} 
Serum levels $(\mu \mathrm{g} . / 100 \mathrm{ml})$. & $1-4$ & $5-10$ & $11-20$ & $21-30$ & $31-40$ & $41-50$ & $51-60$ & $61-70$ \\
No. of assays &. &.. & 12 & 12 & 22 & 18 & 8 & 5 & 2 & 1
\end{tabular}

Table IV.-Amount of Cephaloridine Excreted in 24 Hours (87 Assays)

\begin{tabular}{c|c|c|c|c|c|c|c}
\hline$\mu \mathrm{g} . / \mathrm{ml} .:$ & $\begin{array}{c}401- \\
600\end{array}$ & $\begin{array}{c}601- \\
800\end{array}$ & $\begin{array}{c}801- \\
1,000\end{array}$ & $\begin{array}{c}1,001- \\
1,200\end{array}$ & $\begin{array}{c}1,201- \\
1,400\end{array}$ & $\begin{array}{c}1,401- \\
1,600\end{array}$ & $\begin{array}{c}1,601- \\
1,800\end{array}$ \\
\cline { 2 - 5 } & 6 & 8 & 19 & 12 & 17 & 16 & 9 \\
\hline
\end{tabular}

Cephaloridine was assayed in the pleural exudate of two patients with pleural effusions receiving a daily dose of $2 \mathrm{~g}$., and levels of 30 and $36 \mu \mathrm{g} . / \mathrm{ml}$. were obtained.

Six young males having "clearance" lumbar punctures after recovery from aseptic meningitis were given intramuscular injections of $500 \mathrm{mg}$. of cephaloridine one or two hours before the procedure. Antibiotic levels ranging from 0.03 to 0.25 $\mu \mathrm{g}$. $/ \mathrm{ml}$. were found in the C.S.F.

Table V shows the C.S.F. levels of cephaloridine in patients with septic meningitis 24 hours after intrathecal injection of 100 or $50 \mathrm{mg}$.

Table V.-C.S.F. Levels of Cephaloridine-13 Estimations 24 Hours After Intrathecal Injection

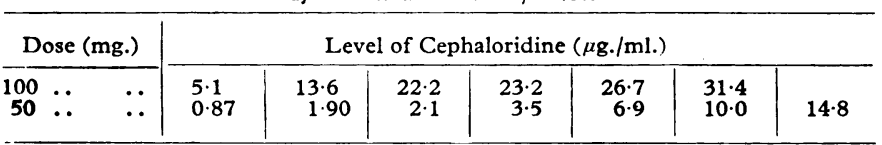

Levels of cephaloridine were measured in the bile of a patient with a biliary fistula following intramuscular injection of $500 \mathrm{mg}$. of the drug. The highest level attained was 2.5 $\mu \mathrm{g} . / \mathrm{ml}$.

\section{Side-effects}

Eight patients complained of fatigue and weakness in the early stage of the trial, but these symptoms were not volunteered latterly and may have been due to an impurity in one of the first batches of antibiotic. Two patients developed skin rashes-one on the ninth day of treatment and the other after discharge from hospital. It is of interest that the latter patient was known to be hypersensitive to ampicillin-unfortunately the rash was not seen. Two patients receiving intrathecal therapy with $100 \mathrm{mg}$. of cephaloridine developed hallucinations and nystagmus, which cleared up spontaneously when the intrathecal injections were discontinued. There was no clinical or biochemical evidence of hepatic or renal dysfunction attributable to the treatment.

\section{Discussion}

Cephaloridine has considerable bactericidal activity against Gram-negative organisms. It is apparently non-toxic and is excreted unchanged in the urine, where high levels are attained. It would therefore seem to be a valuable drug for the treatment of pyelonephritis, apart from the necessity for parenteral administration. In this study 29 patients with refractory urinary infections were treated with cephaloridine. Initial urine sterility was achieved in all instances, but during a follow-up period of three days to three months there were 13 failures-a relapse rate of almost $50 \%$. The treatment of chronic pyelonephritis is, however, notoriously difficult (Syme et al., 1961), and as the period of follow-up is prolonged, relapse or reinfection is more frequently detected in patients with chronic disease (Kleeman et al., 1960). Cephaloridine would therefore seem to be no better than the antibacterial agents at present used for the treatment of chronic pyelonephritis. The patient with acute pyelonephritis or with an acute exacerbation of chronic pyelonephritis is, however, a different problem. These patients may have nitrogen retention and oliguria with or without endotoxin shock. Cephaloridine, with its lack of toxicity, is a useful alternative to potentially toxic antibiotics such as kanamycin in these cases, particularly when facilities are not immediately available for biochemical assessment of renal function. In the anuric patient with Gramnegative infection cephaloridine will also be of value.

Three septicaemic patients were successfully treated with cephaloridine, one requiring two courses of the antibiotic. The two deaths in this group were due to non-infective conditions and the treatment failure to bacteroides superinfection. Because this antibiotic has bactericidal activity against both Grampositive and Gram-negative organisms its use should be seriously considered when a patient is obviously septicaemic, especially in the presence of renal failure before the organism can be identified.

Pneumococcal meningitis is a potentially fatal disease which not uncommonly affects debilitated or elderly patients. Benzylpenicillin is the drug of choice in the treatment of this condition, but some patients do not respond in spite of apparently adequate treatment, and a number of patients are hypersensitive to the penicillins. Three patients suffering from pneumococcal meningitis in the present study were successfully treated with cephaloridine, which is a valuable alternative to benzylpenicillin in this disease. To avoid the possibility of sideeffects the intrathecal dose should not exceed $50 \mathrm{mg}$.

\section{Summary}

Forty-three patients with a variety of infections caused by Gram-positive and Gram-negative organisms were treated with cephaloridine, a new semisynthetic antibiotic, cephaloridine (Ceporin), produced chemically from cephalosporin C.

Treatment was successful in 23 patients and there were four deaths. Thirteen of the treatment failures occurred in patients with refractory urinary infections.

We wish to thank Glaxo Laboratories for generous supplies of cephaloridine. Miss G. Griffen kindly carried out the chemical estimations of cephaloridine in body fluids.

\section{REFERENCES}

Anderson, K. N., and Petersdorf, R. G. (1962). Antimicrob. Agents Chemother., p. 724

Barber, M., and Waterworth, P. M. (1964). Brit. med. F., 2, 344.

Brit. med. F., 1964, 2, 323.

Florey, H. W. (1955). Ann. intern. Med., 43, 480.

Kleeman, C. R., Hewitt, W. L., and Guze, L. B. (1960). Medicine (Baltimore), 39, 85.

Loder, B., Newton, G. G. F., and Abraham, E. P. (1961). Biochem. F.,

79, 408.
Miles, A. A., and Misra, S. S. (1938). 7. Hyg. (Camb.), 38, 732.

Murdoch, J. McC., Geddes, A. M., and Syme, J. (1962). Lancet, 1, 457. Sleigh, J. D., Robertson, J. G., and Isdale, M. H. (1964). F. Obstet. Gynaec. Brit. Cwlth, 71, 74.

Syme, J., Sleigh, J. D., Richardson, J. E., and Murdoch, J. McC. (1961). Brit. F. Urol., 33, 261.

Walters, E. W., Romansky, M. J., and Johnson, A. C. (1962). Antimicrob. Agents Chemother., p. 706. 